\title{
Jobothifetime
}

\section{Information literacy, technology, and forgotten barcodes: The life of a solo academic librarian}

While at the 2007 ACRL National Conference, I caught up with Stephen Spohn, university librarian at the Harrisburg University (HU) of Science and Technology. Over lunch in Baltimore's Harbor Place, Spohn filled me in on why his job is a job of a lifetime.

$\mathrm{HU}$ is a not-for-profit, private university in downtown Harrisburg, Pennsylvania. Students earn bachelor's and master's degrees in programs focused on the industry needs of the Central Pennsylvania region. The university is brand new and still relatively small; the inaugural class of 113 students started in 2005. Spohn is HU's first and only librarian. "I tell people I'm a solo academic librarian. I answer reference questions, deal with budget projections, facilities, the catalog, gifts,

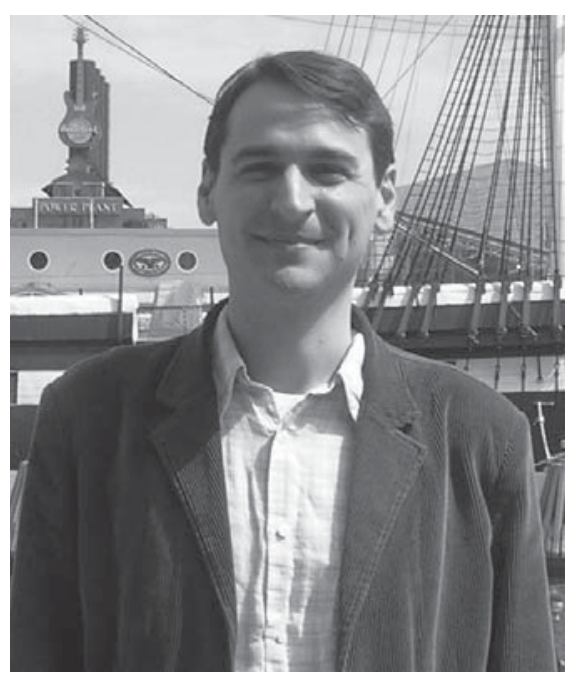

Stephen Spohn, university librarian at Harrisburg University provost's technology across the curriculum committee. Actually, I just started showing up at their meetings. At one, we were talking about core competencies for students. I told them what I think our competencies need to look like, based on information literacy as I see it. I provided them with two things; an overall framework for information literacy, and a way to track student competency at the course level."

Spohn's ideas are a huge success. "The committee members loved it. They're using the structure I created as a model for describing core competencies. I'm really excited."

Spohn's take on information literacy focuses on "product versus process." As he says, "I'm concerned that in general we focus grants, everything. I'm a one person department."

\section{Teaching and learning}

Spohn is no stranger on campus. "One of the lucky things about being so small is that I see the faculty every day. We're equals in the teaching and learning at the university. That's just lucky on my part in getting in on the ground floor."

Spohn is successfully leading the campus initiative for information literacy. "I'm on the too much on this convoluted process rather than focusing on the production of a quality product. Sometimes our faculty have higher expectations for our students than are realistic. Many of our students just haven't been adequately prepared along the way.

"Often a disappointed faculty member will say, 'I just wanted my students to do

Ann Wheeler is the librarian at the Maryland Department of Natural Resources. Have a story idea for Job of a Lifetime? E-mail Ann at awheeler@dnr.state.md.us 
a small research paper, and I wanted to get some critical thinking out of them.' At this point, I'll ask, 'Okay, what do you really want them to do? Do you want them to demonstrate critical thinking, do you want them to write well, or do you want them to learn to do library research? If you really want critical thinking and some depth of understanding, why don't I give students a preconceived search that pulls up all the relevant resources in the area?' I think that you have to show the students that the library has something worth looking for, rather than tell them, 'We've got some great stuff here.' If you let students see the value in what you offer, they'll be hungry for it."

\section{Opening doors with technology}

Spohn is very excited about technology's potential to engage students with the library. "I love technology. I love the way it can enable, facilitate, all those great verbs. I would love to reconceptualize the entire library Web site, and build in a social aspect. I want to bring students there. I want them to recommend things to me and to other students. I want them to leave comments on the library Web site and say, 'Hey Steve, just wanted to say hi, I'm sorry I missed you today.' I want them to be that open. The students are very comfortable with me, and that's the way I want the library to operate. It's not some formal relationship, because that's not going to bring people to the library."

He's also using technology to enhance faculty involvement with the library. "We use the Moodle course management system. I have my own course pages that the faculty can set up, but so far they're not using them. They've started coming to me, asking me to talk to their classes about doing research. Now, I output the library course pages in RSS so that faculty can easily import related library links into Moodle. It's an opportunity to show them these e-course pages where they're able to cherry-pick from all the resources in the database. They log in, they can do whatever they want. As the semester goes on and the needs of the students change, they can change the resources. It's the faculty's opportunity to say, 'Here's the five most important things that you need to be using in this class. If you want to succeed, this is where you want to be."”

\section{Don't forget the barcodes!}

Being a solo librarian often means learning on the job. "I always say if I ever write a book, the title is going to be 'Don't for-

\section{What: Harrisburg University of Science} Where: Harrisburg, Pennsylvania

For more information, visit:

www.harrisburgu.net/campuslife /library/ get the barcodes'... because I did! I was negotiating with our book seller, and was working out all the technical specs. We got through everything, and then he asked, 'Where do you want the barcodes?' I

said, 'Oh, somewhere in the middle,' and he asked 'Well, what's your barcode number?' I thought, I don't know, how do you get that sort of thing?"

Luckily it wasn't too late to rectify his mistake. "I called a barcode company cold, and said, 'Hey, I need barcodes. I'm not sure what I'm doing. So if you could just walk me through the whole thing, that would be great.' And they did!"

Spohn doesn't let little things like forgotten barcodes get him down. Rather, he enjoys the constant change that goes along with being a solo librarian at a new university. "I love change. I embrace change. I go with the flow of change, and I cause a little bit of it myself. I'm not easily frightened about anything." Fearless, and moving forward with some great ideas, Spohn has found a job of a lifetime. $\boldsymbol{z}$ 